\title{
PEMANFAATAN SISTEM INFORMASI MANAJEMEN TERHADAP PENGAMBILAN KEPUTUSAN OLEH KEPALA SEKOLAH
}

\author{
Hana Junesti \\ hanajunesty167@gmail.com \\ Administrasi Pendidikan \\ Universitas Negeri Padang
}

2019

\begin{abstract}
Abstrak
Banyak sekali manfaat dari sistem informasi manajemen khususnya pada bidang pendidikan pada saat sekarang ini sangat diperlukan sekali apalagi untuk kepala sekolah sangat membantu sekali dalam menjalankan tugas-tugas nya. Agar analisis kebijakan dan keputusan yang di ambil dapat memberikan dampak yang bisa di terima oleh semua anggota dan dapat di jadikan sebagai maupun alternatif yang sebaik baiknya, diperlukan informasi yang lengkap benar dan cukup up to date. Agar informasi yang diterima tersebut sifatnya tidak ambigu lagi dan dapat di t erima oleh tenaga pendidik, peserta dan sebagainya maka informasi yang di berikan harus cukup up date . Mewujudkan ide dan keinginan di atas dalam suatu bentuk realitas bukanlah suatu pekerjaan yang mudah tapi bila kita lihat ke negara lain yang telah lama mengembangkan web based distance learning, sudah banyak sekali institusi atau lembaga yang memanfaatkan metode ini. Bukan hanya skill yang dimiliki oleh para engineer yang diperlukan tapi juga berbagai kebijaksanaan dalam bidang pendidikan sangat mempengaruhi perkembangannya dengan adanya system informasi manajemen di bidang pendidikan memudahkan semua pekerjaan tenaga pendidik contoh nya saja dalam pembuatan keputusan oleh kepala sekolah, pengolahan data nila siswa, menyusun anggaran sekolah dan lain-lainnya semua pekerjaan akan selesai dengan cepat menggunakan system informasi tersebut karna dengan adanya sisitem informasi manajemen tersebut kita tidak perlu menghabiskan waktu untuk itu saja karna ssitem informasi manajemen membuat nya jadi mudah .
\end{abstract}


Kata kunci : pemanfaatan sisitem informasi manajemen, pengambilan keputusan

\section{Pendahuluan}

Seiring dengan perkembangan zaman perkembangan teknologi informasi pada saat sekarang ini juga berkembang dengan sangat pesat, munculnya format-format baru kemasan informasi, online access serta arus informasi yang telah membawa konsekuensi luas bagi lembaga pendidikan era ini serta menciptakan kebutuhan layanan yang kompetitif, layanan yang serba cepat, simpel serta memberikan banyak alternatif. Dinas Pendidikan mengembangkan sistem informasi sekolah terpadu dalam pelaporan data pendidikan dari sekolah. Hal ini merupakan langkah terobosan untuk mempermudah pelaporan, akses, dan pembaruan data dari sekolah. Pada zaman era globalisasi dan perdagangan bebas yang akan segera diterapkan, sumber daya manusia yang berkualitas menjadi syarat pokok untuk dapat bersaing. Dan untuk mendapatkan sumber daya manusia yang berkualitas, lembaga Pendidikan mempunyai peran yang sangat vital dalam mencetak sumber daya manusia yang berkualitas dan mampu bersaing dijaman era globalisasi dan Perdagangan Bebas.

Menurut (agustiandra \& sabandi, 2019)dengan pemanfaatan ilmu pengetahuan , dan teknologi yang semamkin berkembang dapat meningkatkan kualitas pembelajaran (Agustiandra \& Sabandi) .

Berdasarkan Peraturan Pemerintah No. 19 Tahun 2005 tentang Standar Nasional Pendidikan Khususnya Standar Sarana dan Prasarana pasal 46 ayat (1) menjelaskan bahwa "satuan pendidikan yang memiliki peserta didik, pendidik, dan/atau tenaga kependidikan yang memerlukan layanan khusus, wajib menyediakan akses ke sarana prasarana yang sesuai dengan kebutuhan mereka".

Dalam suatu lembaga pendidikan Kepala sekolah merupakan ujung tombak dari pencapaian visi dan misi sekolah, serta sebagai penentu arah dari kebijakan yang diterapkan di suatu sekolah seorang kepala Sekolah sebagai juga sebagai seorang tenaga fungsional guru yang diberikan suatu tugas untuk memimpin suatu sekolah dimana yang diselenggarakan proses belajar dan mengajar, atau tempat dimana terjadi interaksi antara tenaga pendidik yang memberi pelajaran dan murid sebagai penerima pelajaran. Maka setiap kebijakan yang diputuskan oleh kepala sekolah menjadi kewajiban yang 
harus dilaksanakan oleh warga sekolah dalam rangka pencapaian visi misi dan tujuan pendidikan disuatu sekolah. Kemampuan kepala sekolah dalam memimpin dan mengambil keputusan tidak terlepas dari kecerdasan emosional yang dimiliki. Kecerdasan emosional memiliki pengaruh dalam kehidupan manusia, tergantung manusia itu sendiri mengelola atau memanfaatkan kecerdasan yang dimilikinya dalam hal yang positif atau negative . 


\section{PEMBAHASAN}

\section{Pengertian sisitem informasi}

Sistem informasi adalah banyaknya kumpulan perangkat-perangkat yaitu seperti hardware, software, brainware, prosedur dan atau aturan yang diorganisasikan secara integral untuk mengolah sebuah data menjadi informasi yang bermanfaat dan sangat berguna untuk menyelesaikan suatu masalah dan pengambilan keputusan dan sangat berguna sekali dalam bidang manajemen pendidikan

Sistem informasi adalah satu kesatuan data olahan yang terintegrasi dan saling melengkapi yang dapat memberikan hasil sesuatu baik dalam bentuk data output yang baik dalam bentuk gambar, suara maupun tulisan. Sistem informasi adalah sekumpulan komponen-komponen yang dapat membentuk sistem yang mempunyai saling keterkaitan antara satu komponen dengan komponen yang lainya . dan bertujuan menghasilkan suatu informasi dalam suatu bidang tertentu. Dalam sistem informasi diperlukannya adanya suatu klasifikasi alur informasi yang fleksibel, hal ini disebabkan Karena adanya keanekaragaman kebutuhan akan suatu sistem informasi olehorangorang yang ingin menggunakan informasi tersebut . Kriteria dari sistem informasi antara lain : fleksibel, efektif dan efisien. Pengertian sistem menurut Kamus Besar Bahasa Indonesia (1999 : 950), "Sistem suatu adalah perangkat unsur yang secara teratur saling berkaitan sehingga membentuk suatu totalitas". Lucas dalam bukunya Wahyudi Komorotomo dan Subando Agus M (2004:8) mengatakan, "secara sederhana suatu sistem dapat diartikan sebagai suatu kumpulan atau himpunan dari unsur, komponen, atau variabel-variabel yang terorganisasi, saling berinteraksi, saling tergantung satu sama lain dan terpadu".

Sedangkan sistem Informasi Manajemen Akademik (agustiandra \& sabandi, 2019) adalah segala macam hasil interaksi antara elemen di lingkungan akademik untuk menghasilkan informasi yang kemudian dijadikan landasan pengambilan sebuah keputusan. Hal yang sama juga diungkapkan oleh Hartono (2013, dalam Vindia dan Sabandi 2019:1) SIM adalah sebuah sistem, yaitu rangkaian yang terorganisasi dari sejumlah bagian/komponen yang secara bersama-sama berfungsi atau bergerak menghasilkan informasi untuk digunakan dalam manajemen perusahaan . 


\section{Sekolah sebagi system}

Sekolah sebagai sistem, maksudnya yaitu semua elemen yang ada di dalam instansi sekolah maupun suatu unsur yang ada di lingkungan sekolah sebagai satu kesatuan yang utuh, tidak dapat terpisahkan antara satu dengan yang lainnya, seperti siswa, guru, kepala sekolah, gedung, alat peraga, dan perangkat pembelajaran dan sebagainya. Dalam era kemandirian sekolah dan era Manajemen Berbasis Sekolah (MBS), tugas dan tanggung jawab yang pertama dan yang utama dari para pimpinan sekolah adalah menciptakan sekolah yang mereka pimpin menjadi suatu sekolah yang nyaman dan efektif, maksudnya yaitu dapat memberikan manfaat bagi sekolah itu sendiri dan untuk semua orang dan bagi masyarakat luas yang menggunkannya. Agar tanggung jawab seorang pemimpin sekolah itu dapat terlihat atau nyata, sebaiknya para pemimpin tersebut perlu memahami dan mendalami, dan menerapkan beberapa konsep ilmu manajemen yang sudah berkembang oleh pemikir-pemikir dalam dunia bisnis. Manakala diperdalam secara sungguh-sungguh, kiranya konsep-konsep ilmu manajemen tersebut memiliki suatu nilai (dalam arti values) yang tidak akan menjerumuskan dunia pendidikan kita ke arah bisnis yang dapat merugikan atau mengecewakan masyarakat luas penggunanya (Thomas B. Santoso, 2001) .

\section{Konsep dasar informasi}

1. Yaitu suatu data yang diolah menjadi suatu bentuk yang lebih mempunyai manfaat serta lebih memberikan suatu arti bagi orang-orang yang mendapatkannya

2. Sesuatu yang bentuknya nyata atau bisa juga hanya sebagian nyata yang bisa mengurangi suatu bentuk ketidak pastian mengenai suatu keadaan atau kejadian.

\section{Manfaat sisitem informasi manajemen bagi pendidikan}

a. Dapat meningkatkan suatu aksebilitas suatu daya yang akan di sajikan secara tepat waktu dan akurat bagi orang-orang yang yang ingin memakinya tanpa harus adanya sebuah perantara

b. Mampu mengembangkan suatu proses perencanaan dan kegiatan manajemen yang telah sesuai dengan tujuan yang telah di tetapkan sebelumnya

c. Sebagai alat untuk keberhasilan kebutuhan suatau instansi sekolah 
d. Data-data rahasia sekolah bisa aman terjaga kerahasiaannya dengan sisitem informasi manajemen tersebut

e. Memperbaiki sebuah kinerja di setiap instansi sekolah pada bidang manajemen dengan menggunakan sisitem informasi manajemen

f. Suatu instansi sekolah dapat menggunakan sisitem informasi untuk mengolah datadata dan dapat mengurangi biaya pengeluaran sekolah

g. Dapat mendukung suatu pengambilan keputusan oleh kepala sekolah

h. Mendukung tercapainya keunggulan suatu instansi sekolah tersebut .

\section{Tujuan Sistem Informasi Manajemen Pendidikan}

a. Dapat membantu suatu bagian yang berperan di dalam dunia pendidikan dengan adanya informasi yang secara menyeluruh tentang pendidikan dari tingkat sekolah dasar sampai sekolah menengah umum maupun yang setara dengan pendidikan itu

b. Memberikan suatu sarana suatu instansi pendidikan dapat berperan aktif dalam usaha memajukan pendidikan tersebut

c. Adanya ertanggunggungjwaban dari public tentang kebijakan dan tentang kebijakan pemakaian sumber daya yang telah di alokasikan dalam instansi pendidikan tersebut

d. Meningkatkan pengetahuan drai tenaga pendidik dan peserta didik tentang dunia informatika pada saat sekarang ini serta dampak positif yang dapat di jadikan suatu pelajaran

e. Memberikan aksese innformasi yang mudah di dapatkan oleh pesrta didik tentang ilmu pengetahuan dan sebaginya .

\section{Keputusan Kepala Sekolah}

Kepala sekolah adalah merupakan ujung tombak dari pencapaian visi dan misi sekolah dan pencaian tujuan dari sekolah itu sendiri, serta penentu arah dari kebijakan yang diterapkan di suatu sekolah. Kepemimpinan merupakan suatu elemen yang sangat penting dalam mencapai, mempertahankan dan meningkatkan kinerja organisasi., sehingga kepala sekolah mampu berperan aktif dalam menjalankan tugasnya, serta sesuai dengan wewenang yang telah ada. Kepala sekolah harus melakukan tindakan sebagai manajer danharus mampu menjadi pemimpin yang efektif bagi bawahannya. Sebagai seorang manajer ia harus mampu mengatur agar semua potensi sekolah dapat berfungsi sesuai dengan fungsinya masing-masing. Secara tidak langsung seorang 
kepala sekolah memegang erat suksesnya prosese belajar ,men ajar dalam instansi pemdidikan terebut harapan orang tua yang besar terkondisikan kepada kepercayaan menyekolahkan putra-putrinya pada sekolah tertentu dan menggantungkan cita-citanya dan harapannya pada kepala sekolah tersebut dengan penuh harap agar putra-putrinya bisa menjadi orang yang sukses nantinya dengan kepla sekolah yang mamapu mengendalikan manajemen pendidikan yang ada dalam instansi pendidikan tersebut .

\section{Kepala Sekolah Sebagai Pengambil Keputusan}

Peranan seorang pemimpin atau kepala sekolah sebagai pengambil keputusan merupakan peranan yang paling penting dari peranan yang lainnya . namun dalam mengambil sebuah keputusan seorang kepala sekolah harus memperhatikan hal-hal sebagai berikut :

a. apa sebab yang akan terjadi maupun akibat yang akan terjadi bila kepala sekolah tersebut mengambil keputusan itu

b. kepala sekolah harus bisa membuat hubungan yang baik antara pihak luar agar bisa membicarakan dan membuat keputusan apa yang tepat nantinya

c. kepala sekolah juga harus mampu menyediakan sarana dan prasarana sekolah yang memadai agar nantinya mamapu menunjang proses belajar mengajar yang terjadi dalam sekolah tersebut dengan baik 


\section{DAFTAR PUSTAKA}

agustiandra, v., \& sabandi, a. (2019). persepsi guru terhadap penerapan sistem informasi manajemen akademik di sekolah menengah kejuruan (SMK) negeri 3 padang. jurnal bahana manajemen pendidikan, 8(1), 1-8.

Nazir. (2003). metode penelitian. jakarta: ghalia indonesia.

purwanto, n. (2005). administrasi dan supervisi pendidikan. bandung: remaja rosda karya. 